\title{
LIFE CYCLE OF DISCUS RUDERATUS (FÉRUSSAC, 1821) (GASTROPODA: PULMONATA: ENDODONTIDAE)
}

\author{
ELŻBIETA KUŹNIK-KOWALSKA
}

\author{
Department of Zoology and Ecology, Agricultural University, Kożuchowska 5b, 51-637 Wrocław, Poland \\ (e-mail: ekow@ozi.ar.wroc.pl)
}

\begin{abstract}
Life cycle of Discus ruderatus (Fér.) was studied in the laboratory, with occasional field observations. No courtship or copulation could be observed; uniparental reproduction is very rare. In the laboratory the eggs are laid in all months, with maximum in June/July and December/January, in the field the youngest age class appears in May. The eggs are laid on rotting timber; they are calcified, nearly sphaerical, ca. $1.5 \mathrm{~mm}$ in major diameter; the number of eggs per batch is $1-6$ (mostly 3-4), with a total of $6-15$ eggs in 2-5 batches per lifetime. The incubation period is 17-34 days, hatching is nearly synchronous; the hatching success is ca. $54 \%$. The hatchlings have shells of 1.5-2.5 whorls; they consume their egg envelopes immediately after hatching. The egg cannibalism is prolonged into adult stage. The overall mean growth rate is 1 whorl per ca. 179 days (54 days per whorl till maturity, 487 days per whorl in mature snails). The snails reach maturity at slightly over 4 whorls (mature gametes present in the gonad), the mean life span is 580 days, the reproductive life constituting ca. $35 \%$ total life span. Life cycle parameters of three members of Discus are discussed comparatively.
\end{abstract}

KEY WORDS: terrestrial pulmonates, Discus ruderatus, life cycle, growth, reproduction

\section{INTRODUCTION}

This is the third paper devoted to the life cycles of members of the genus Discus Fitzinger, 1833. The previous two dealt with $D$. rotundatus (O. F. Müll.) (KUŹNIK-KOWALSKA 1999) and D. perspectivus (Mühlf.) (KUŹNIK-KOWALSKA 2005); the importance of such studies and the extent of knowledge of life cycles of terrestrial pulmonates in general have been discussed in introductory chapters of these two publications, and in MALTZ (2003). The aim of this paper is to present the life history of $D$. ruderatus (Fér.), and to discuss life cycles of the three species of Discus in a broader context.

D. ruderatus is a Palaearctic species of a rather wide distribution range, though with many gaps. In the north, in places it reaches the coast of Arctic Sea (Arkhangelsk, in Norway to $71^{\circ} \mathrm{N}$ ), in the south it is found in the Crimea, the Caucasus and the northern part of Armenian Upland. In Poland it has been recorded from many sites, especially in the mountains: Sudetes, Świętokrzyskie Mts, Tatra and Carpathians with the Subcarpathian region; it is also known from natural lowland forests, e.g. Białowieża or some sites in the Mazurian Lakeland. In the Karkonosze Mts it lives at 600-1,200 $\mathrm{m}$ a.s.1., in the Tatra it reaches up to 1,900 m a.s.l. (UMIŃSKI 1962, RIEDEL \& WIKTOR 1974, WIKTOR 2004). D. ruderatus is a forest-dweller, strongly associated with rotting timber; it shelters under tree bark, in rotting timber and in leaf litter. It inhabits both deciduous and coniferous forests, and is regarded as an indicator of rather cool and humid forest areas.

\section{MATERIAL AND METHODS}

\section{LABORATORY OBSERVATIONS}

Material for the laboratory culture (snails of various ages, eggs) was collected on various occasions be-

tween May 26th 1996 and May 25th 1997 in two localities in Poland: the Eastern Sudetes, Kletno, massif of Śnieżnik Kłodzki ( $\left.50^{\circ} 16^{\prime} \mathrm{N}, 16^{\circ} 52^{\prime} \mathrm{E}\right)$ and in Podlasie, Białowieża $\left(52^{\circ} 42^{\prime} \mathrm{N}, 23^{\circ} 52^{\prime} \mathrm{E}\right)$. 
The laboratory observations were conducted from May 26th 1996 till November 30th 1999. The total number of individuals kept in the laboratory was 108 , originating from 22 snails and eggs collected in the field. The snails were kept in Petri dishes, of a diameter depending on the number of individuals ( $\varnothing 5-14$ $\mathrm{cm}$ ), on a humid tissue paper with pieces of rotting wood. The snails ate mainly microflora developing on the rotting timber (FRÖMMING 1954). Their diet was supplemented with lettuce, cabbage, carrot, cucumber and apple. Hen egg shells were placed in the dishes as a source of calcium. The temperature ranged from $17^{\circ} \mathrm{C}$ in winter to $25^{\circ} \mathrm{C}$ in summer, the humidity was constant, of ca. $100 \%$. The dishes were aired once a week, food and water being added when necessary.

In order to check the possibility of uniparental reproduction, snails were kept singly from the egg or early juvenile stages; in order to observe mating they were kept in pairs and groups of several individuals: 38 isolated individuals, 70 in pairs (10 pairs) and groups of 3-20.

Observations on egg cannibalism included 31 juvenile and 26 adult snails and, as food, 400 eggs of $D$. rotundatus and $D$. ruderatus. Two food choice tests were used: Test I: 12 snails aged 7 days, kept in a dish, $\varnothing 10 \mathrm{~cm}$, during 30 days, were offered 41 eggs of $D$. rotundatus and 19 conspecific eggs (see Table 2 ). Test II: 7 newly hatched snails kept in a dish, $\varnothing 10 \mathrm{~cm}$, during 7 days, were offered 26 eggs of $D$. rotundatus and 19 conspecific eggs (Table 2 ). Test III was aimed at determining the growth rate in cannibalistic individuals: 12 juveniles were kept singly in dishes, $\varnothing 5 \mathrm{~cm}$, and fed only conspecific eggs, till maturity (Table 3). In tests I and II the snails were given lettuce as supplementary food; the number of eaten or damaged eggs of each species were estimated. In test III the shell increments were monitored.

Growth rate was measured for both cannibalistic and non-cannibalistic individuals; whorls were counted according to EHRMANN's (1933) method. Eggs $(n=60)$ were measured with calibrated eye-piece, to the nearest $0 \times 0.025 \mathrm{~mm}$.

Standard histological slides were made of gonads of snails collected in Bardo Śląskie (Poland: Sudetes: $50^{\circ} 31^{\prime} \mathrm{N}, 16^{\circ} 46^{\prime} \mathrm{E}$; June 2nd 1997, 13 specimens of 3.5-5.3 whorls) in order to determine when mature gametes appeared in the gonads. The snails were dissected and their gonads preserved in the Bouin fixative, dehydrated in a graded ethanol series and xylene or toluene, embedded in paraffin, cut into $4 \mu \mathrm{m}$ sections, deparaffinated in toluene and a graded ethanol series, rinsed in distilled water and stained with Delafield haematoxylin and eosin.

Statistical analysis was performed with Statistica, PL. 5.1 using the test for statistical difference between the means and the Spearman correlation (STANISZ 1998).

\section{FIELD OBSERVATIONS}

Because of the difficult accessibility of the sites, and the low population density, only sporadic field observations were made; contrary to D. rotundatus and $D$. perspectivus, the growth rate and age structure were not studied in the field.

\section{RESULTS}

Despite numerous attempts, no courtship or copulation could be observed either in the laboratory, or in the field.

\section{LABORATORY OBSERVATIONS}

Egg laying, incubation and hatching

In the laboratory D. ruderatus laid eggs on pieces of rotting timber, and often also on tissue paper, lettuce leaves, in empty shells of its own species or on hen egg shells. The eggs were laid by individuals kept in groups and pairs; only one of the individuals kept singly laid eggs. Newly laid eggs were calcified, almost sphaerical, white, intially shiny because of the fresh mucus covering, then, after 5-7 days, matt. Their major diameter was ca. $1.5 \mathrm{~mm}(1.1-1.3 \times 1.2-1.5$; mean $1.29 \times 1.50 ;$ SD 0.59 and $0.69 ; \mathrm{n}=60)$ (Fig. 1). The egg size was not correlated with the number of whorls of the parent. The number of eggs per batch was 1-6 (mean 2.97; SD 1.049; n = 40) (Fig. 2). Most batches were composed of 3-4 eggs arranged in a characteristic pyramid or row (Fig. 3). The eggs laid by the only isolated individual that reproduced (10 eggs in 3 batches) did not depart in their size from those laid by snails kept in pairs or groups; four normally developing juveniles hatched from them. In the laboratory D. ruderatus laid eggs throughout the year, with maxima in June/July and December/January (Fig. 4). The number of eggs produced per lifetime ranged from 6 to 15 (mean 11.55 ; SD $2.78 ; \mathrm{n}=20$ ), the number of batches was $2-6$ (mean 4.85 ; SD $1.35 ; \mathrm{n}=20$ ). The number of eggs and batches and their distribution in time varied widely between individuals (Table 1 ).

The duration of the incubation period ranged from 17 to 34 days (mean 25.00; SD 4.14; $\mathrm{n}=30$ ) (Fig. $5)$. Hatching was nearly synchronous within batches, i.e. all juveniles in a batch hatched within a few to about a dozen hours. Hatching lasted 1.5-3 hours. Since the eggs were opaque, it was impossible to observe if the juvenile used its radula to disrupt the egg 


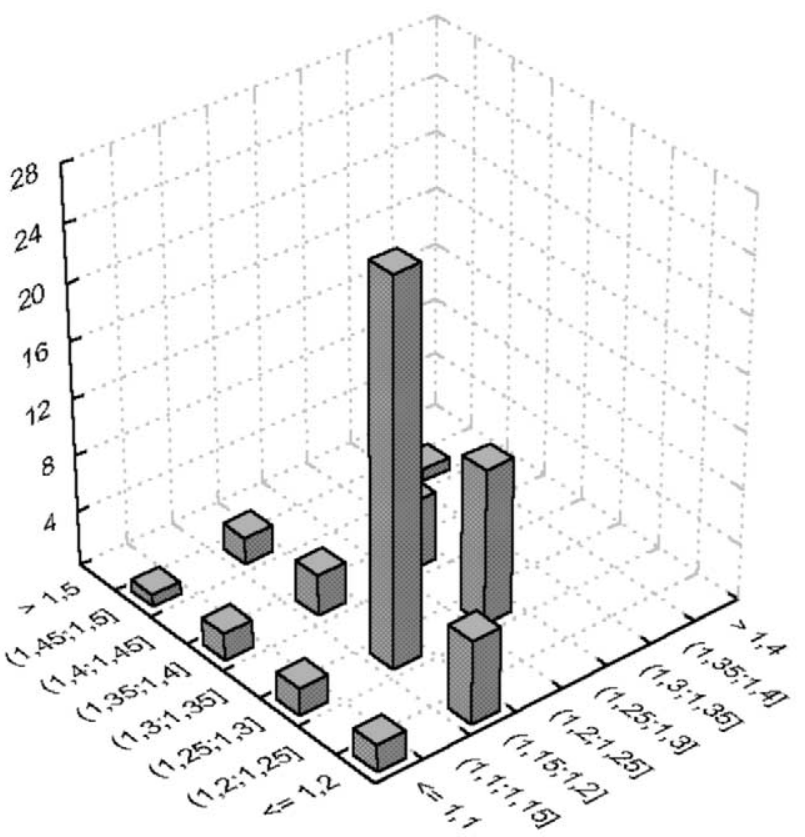

Fig. 1. Egg measurements in D. ruderatus - two diameters $[\mathrm{mm}], \mathrm{n}=60$

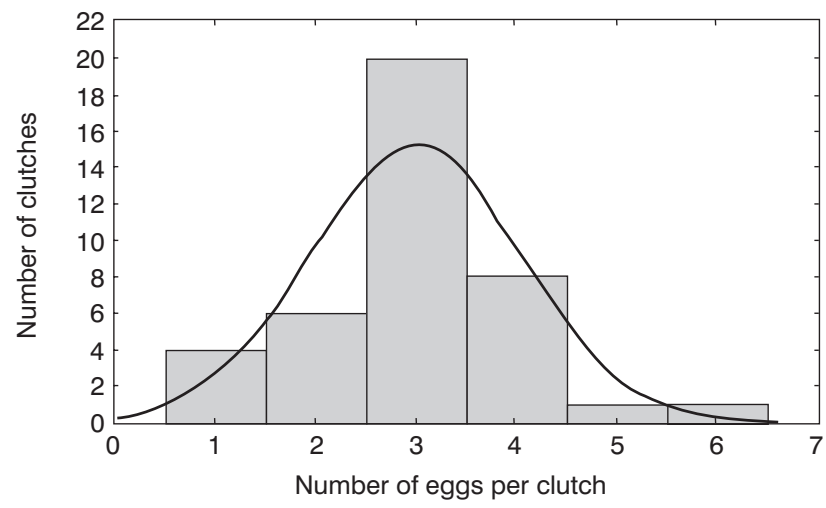

Fig. 2. Distribution of the number of eggs per batch in $D$. ruderatus

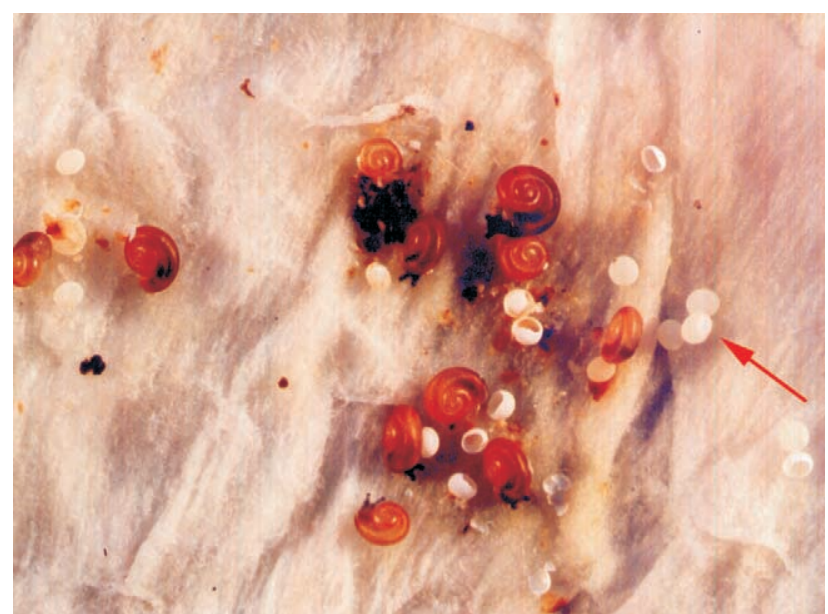

Fig. 3. D. ruderatus and its egg batches (arrow)

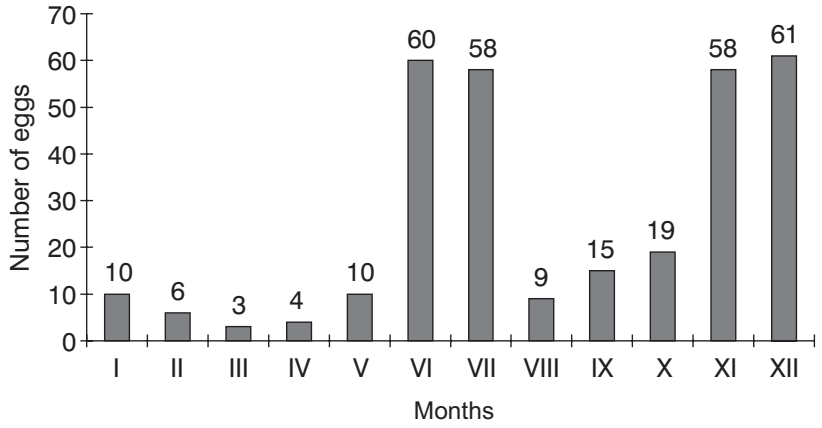

Fig. 4. Total number of eggs laid in 12 consecutive months (Roman numerals) by 25 individuals of $D$. ruderatus

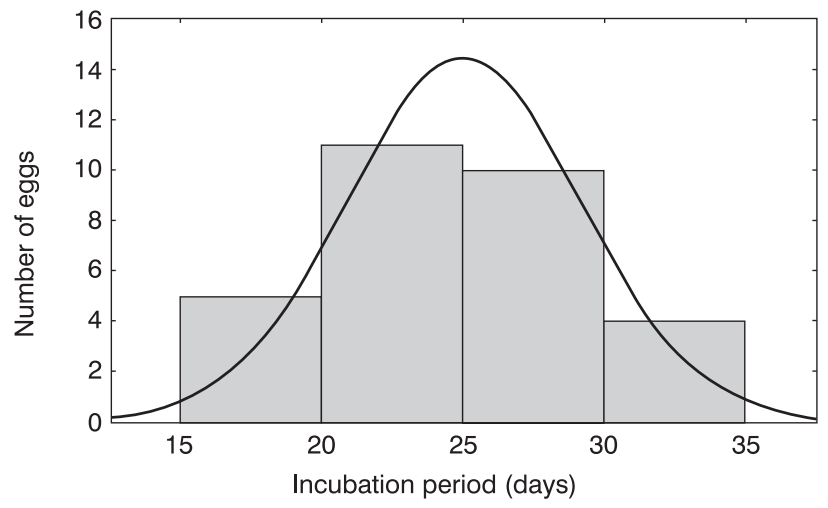

Fig. 5. Distribution of incubation period duration in $D$. ruderatus

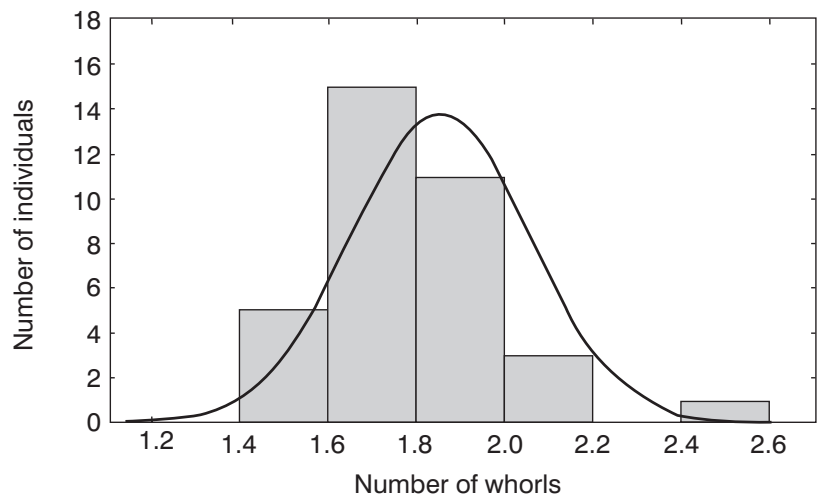

Fig. 6. Distribution of the number of whorls in hatchlings of D. ruderatus

envelopes. From the outside the first sign of hatching was a small fragment of the egg shell breaking off. Hatchlings had translucent shells and bodies. Their shells had 1.5-2.5 whorls (mean 1.85; SD 0.20; $\mathrm{n}=35$ ) (Fig. 6). The first 1.25-1.8 whorl was always smooth, the remaining part bore 1-3 first ribs of definitive whorls. Juvenile snails were very active and immediately started feeding, first consuming their egg shell. The hatching success for eggs laid by individuals kept in pairs and groups was $53.85 \%(\mathrm{n}=60)$.

Cannibalis m

In the laboratory, juveniles of various ages were observed to consume conspecific eggs; newly hatched juveniles ate eggs from both their own and alien 
Table 1. D. ruderatus. Egg laying by 10 individuals

\begin{tabular}{ccccc}
\hline Individual number & $\begin{array}{c}\text { Number of whorls } \\
\text { (first and last egg) }\end{array}$ & First and last egg & Number of batches & Number of eggs \\
\hline 1 & $4.2-5.7$ & $30.11 .1996-11.02 .1997$ & 5 & 14 \\
2 & $4.4-4.9$ & $16.11 .1996-15.12 .1996$ & 6 & 13 \\
3 & $4.3-4.75$ & $20.11 .1996-17.12 .1997$ & 6 & 15 \\
4 & $4.9-5.5$ & $1.07 .1996-15.05 .1997$ & 3 & 9 \\
5 & $4.0-5.4$ & $15.04 .1996-5.09 .1997$ & 6 & 14 \\
6 & $4.2-5.0$ & $15.07 .1996-2.02 .1997$ & 6 & 6 \\
7 & $4.9-4.9$ & $19.11 .1996-20.11 .1996$ & 2 & 9 \\
9 & $4.1-4.1$ & $15.07 .1996-17.07 .1996$ & 3 & 5 \\
10 & $4.0-5.2$ & $25.06 .1996-20.11 .1996$ & 5 & 12 \\
\hline
\end{tabular}

Table 2. Egg selection by cannibalistic juveniles of $D$. ruderatus

\begin{tabular}{cccc}
\hline Test number & Number of individuals & $\begin{array}{c}\text { Eggs of D. ruderatus } \\
\text { (offered/eaten/damaged) }\end{array}$ & $\begin{array}{c}\text { Eggs of D. rotundatus } \\
\text { (offered/eaten/damaged) }\end{array}$ \\
\hline I & 12 & $19 / 10 / 3$ & $41 / 16 / 15$ \\
II & 7 & $4 / 3 / 1$ & $26 / 2 / 8$ \\
\hline
\end{tabular}

Table 3. Growth rate of 10 selected D. ruderatus fed with conspecific eggs (size at the first egg-laying indicated with bold)

\begin{tabular}{cccccccccccc}
\hline \multirow{2}{*}{ Date } & \multicolumn{10}{c}{ Individual number } \\
\cline { 2 - 12 }$y$ & 1 & 2 & 3 & 4 & 5 & 6 & 7 & 8 & 9 & 10 \\
\hline 19.04 .1999 & 1.75 & 1.9 & 1.8 & 1.8 & 1.7 & 1.7 & 1.8 & 1.8 & 1.8 & 1.9 \\
12.05 .1999 & 2.1 & 2.4 & 2.4 & 2.4 & 2.5 & 2.25 & 2.25 & 2.3 & 2.25 & 2.25 \\
28.05 .1999 & 2.4 & 2.8 & 2.9 & 2.6 & 2.75 & 2.6 & 2.6 & 2.8 & 2.5 & 2.6 \\
6.07 .1999 & 3.4 & 3.6 & 3.7 & 3.4 & 3.6 & 3.5 & 3.5 & 3.6 & 3.3 & 3.2 \\
6.08 .1999 & 4.0 & 4.1 & $\mathbf{4 . 3}$ & 4.0 & $\mathbf{4 . 4}$ & $\mathbf{4 . 3}$ & 4.4 & $\mathbf{4 . 4}$ & 3.9 & 3.9 \\
6.09 .1999 & $\mathbf{4 . 5}$ & $\mathbf{4 . 5}$ & 4.6 & $\mathbf{4 . 5}$ & 4.9 & 4.8 & $\mathbf{4 . 6}$ & 4.9 & $\mathbf{4 . 3}$ & $\mathbf{4 . 4}$ \\
\hline
\end{tabular}

batches. Adults, even when other food was available, sometimes consumed eggs, including their own; when no other food was available they did it regularly (10 observations). No cannibalism adult-juvenile or adult-adult was observed. One of singly kept individuals consumed four out of the 10 eggs it produced. The results of food preference tests for cannibalistic juvenile $D$. ruderatus are presented in Table 2, the growth rate of individuals fed only with conspecific eggs - in Table 3.

\section{Growth and maturation}

Formation of one whorl in growing D. ruderatus took from 115.8 to 276.84 days (mean 178.58; $\mathrm{SD}=$ $58.96 ; \mathrm{n}=20$ ). Growth of 10 selected individuals is presented in Table 4 and Fig. 7. The growth proceeded in two phases: I - fast phase, from hatching to maturity (41.18-60.44 days/whorl, mean 51.38; $\mathrm{SD}=6.18 ; \mathrm{n}=$ 10); II - slow phase, from maturity to death
(213.33-745.55 days/whorl, mean 486.868; $\mathrm{SD}=$ $180.91 ; \mathrm{n}=10)$. The time between hatching and maturity as manifest by the number of whorls (4.0) ranged from 89 to 102 days (mean $94 ; \mathrm{SD}=5.01 ; \mathrm{n}=20$ ).

Sexual maturity (as indicated by the first egg laid, morphological characters of the reproductive system, gamete production, see below) was attained by individuals of at least four whorls, but in some instances first eggs were laid by bigger individuals, of up to 4.9 whorls (Table 5). Among 60 dissected $D$. ruderatus of 3.5 to 5.3 whorls, only those of four or more whorls had morphologically mature reproductive system $(n=28)$. The time from hatching to the first egg laying ranged from 90 to 176 days (mean 119.35; SD 23.33; $\mathrm{n}=20)$. Mature gametes appeared at the earliest at the shell size of 4.0-4.2 whorls (Fig. 8 ); gonads of smaller individuals (3.5 whorls) contained only oocytes and spermatocytes at different stages of development. 
Table 4. Growth rate of 10 selected D. ruderatus normally fed (size at the first egg-laying indicated with bold)

\begin{tabular}{|c|c|c|c|c|c|c|c|c|c|c|}
\hline \multirow{2}{*}{ Date } & \multicolumn{10}{|c|}{ Individual number } \\
\hline & 1 & 2 & 3 & 4 & 5 & 6 & 7 & 8 & 9 & 10 \\
\hline 7.08 .1996 & 2.2 & 2.0 & 2.0 & 1.8 & 2.1 & 1.9 & 1.75 & 1.8 & 2.0 & 2.15 \\
\hline 5.09 .1996 & 2.8 & 2.5 & 2.65 & 2.55 & 2.7 & 2.5 & 2.4 & 2.5 & 2.6 & 2.9 \\
\hline 10.10 .1996 & 3.6 & 3.6 & 3.5 & 3.75 & 3.5 & 3.7 & 3.5 & 3.7 & 3.4 & 3.7 \\
\hline 10.11.1996 & 4.3 & 4.4 & 4.3 & 4.3 & 4.2 & 4.3 & 4.0 & 4.2 & 4.1 & 4.5 \\
\hline 9.12 .1996 & 4.75 & 4.9 & 4.6 & 4.6 & 4.6 & 4.7 & 4.5 & 4.6 & 4.5 & 4.7 \\
\hline 13.01.1997 & 4.9 & 5.0 & 4.75 & 4.7 & 4.9 & 5.0 & 4.8 & 4.75 & 4.8 & 4.7 \\
\hline 4.03 .1997 & 5.1 & 5.0 & 5.1 & 5.0 & 5.0 & 5.0 & 5.0 & 4.9 & 5.0 & 4.75 \\
\hline 8.04 .1997 & 5.2 & 5.1 & 5.1 & 5.25 & 5.1 & 5.0 & 5.0 & 5.1 & 5.1 & 4.9 \\
\hline 15.05.1997 & 5.25 & 5.1 & 5.1 & 5.25 & 5.2 & 5.1 & 5.1 & 5.1 & 5.2 & 5.0 \\
\hline 11.12 .1997 & 5.25 & & 5.2 & 5.25 & 5.2 & 5.0 & & 5.1 & 5.2 & 5.0 \\
\hline 15.07.1998 & & & & & 5.2 & & & 5.1 & 5.2 & 5.0 \\
\hline
\end{tabular}

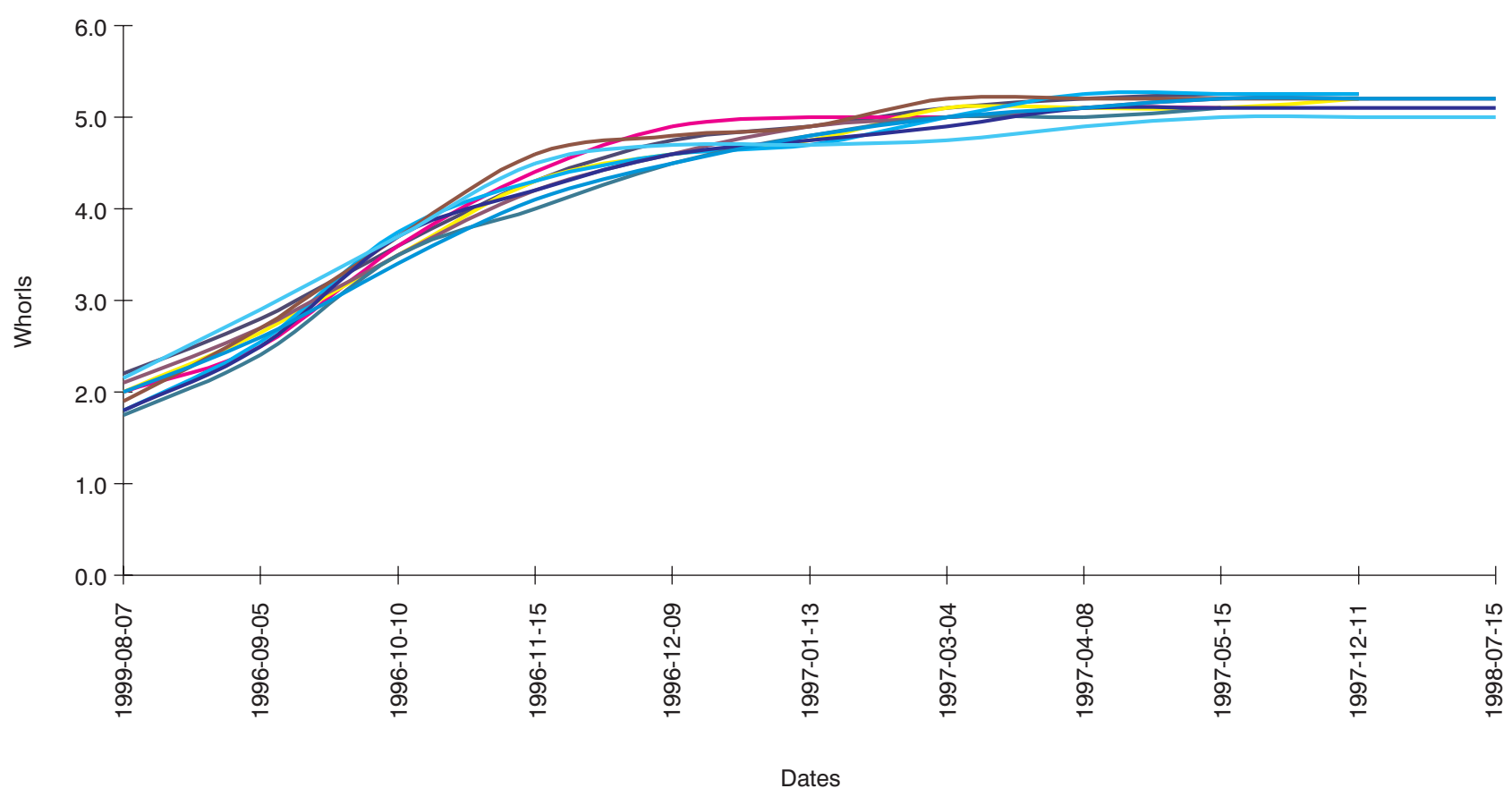

Fig. 7. Growth curves of 10 selected individuals of D. ruderatus

Table 5. Life histories of selected non-isolated (1-7) and isolated (8-10) individuals of D. ruderatus

\begin{tabular}{cccccccc}
\hline $\begin{array}{c}\text { Individual } \\
\text { number }\end{array}$ & Hatching & First egg & $\begin{array}{c}\text { Number of } \\
\text { whorls }\end{array}$ & Last egg & $\begin{array}{c}\text { Number } \\
\text { of whorls }\end{array}$ & Death & $\begin{array}{c}\text { Number } \\
\text { of whorls }\end{array}$ \\
\hline 1 & in the field & 30.11 .1996 & 4.2 & 11.02 .1997 & 5.7 & 15.11 .1997 & 5.7 \\
2 & 27.07 .1996 & 20.11 .1996 & 4.3 & 17.12 .1996 & 4.75 & 1.12 .1997 & 5.25 \\
3 & 27.07 .1996 & 16.11 .1996 & 4.4 & 15.12 .1996 & 4.9 & 3.05 .1997 & 5.1 \\
4 & 6.01 .1996 & 1.07 .1996 & 4.9 & 15.05 .1997 & 5.5 & 10.12 .1997 & 5.5 \\
5 & 15.01 .1996 & 15.04 .1996 & 4.0 & 5.09 .1997 & 5.4 & 5.12 .1997 & 5.5 \\
6 & 9.04 .1996 & 15.07 .1996 & 4.2 & 2.02 .1997 & 5.0 & 21.05 .1997 & 5.0 \\
7 & in the field & 19.11 .1996 & 4.9 & 20.11 .1996 & 4.9 & 11.12 .1997 & 5.3 \\
8 & in the field & 15.07 .1996 & 4.1 & 17.07 .1996 & 4.1 & 5.04 .1997 & 5.0 \\
9 & in the field & 25.06 .1996 & 4.0 & 20.11 .1996 & 5.2 & 14.07 .1998 & 5.5 \\
\hline
\end{tabular}




\section{Life span}

The life span ranged from 280 to 789 days (mean 580; SD 163.97; $\mathrm{n}=20$ ), the time elapsing between the last egg and death was 87-521 days (mean 238.53; SD $131.17 ; \mathrm{n}=20$ ). The reproductive life was ca. $35.3 \%$ life span.

\section{FIELD OBSERVATIONS}

In the field D. ruderatus laid eggs in humid, sheltered places; most eggs found in the field were placed in rotting timber.

Samples taken sporadically in Kletno (massif of Śnieżnik Kłodzki, Sudetes, SW. Poland) and in Białowieża (Podlasie, E. Poland) in May and October indicate that the youngest age class appears already in May and becomes much less numerous by October.

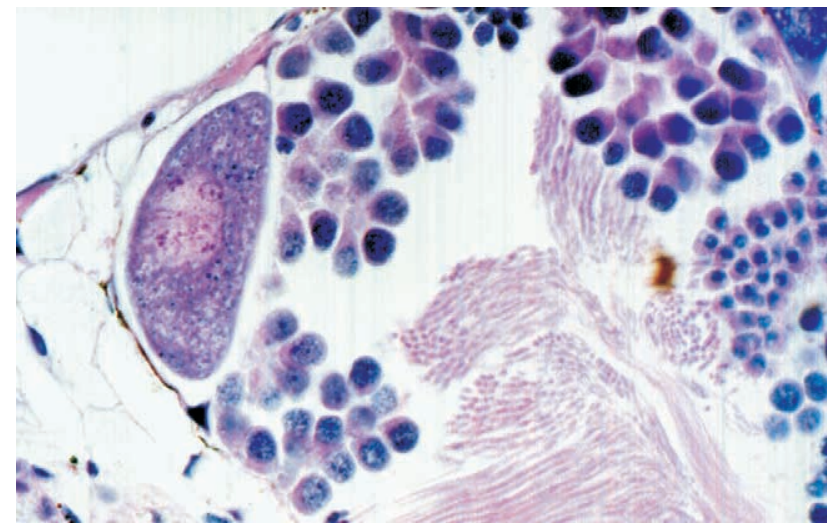

Fig. 8. D. ruderatus. Mature gonad of a specimen of 4.2 whorls. $100 \times$

\section{DISCUSSION}

Since this is the last of the three papers dealing with life cycles of the members of Discus (the previous ones dealt with D. rotundatus, KUŹNIK-KOWALSKA 1999 and D. perspectivus, KUŹNIK-KOWALSKA 2005), the aim of this discussion is mainly to compare the components of the life cycle and reproductive strategies in three congeneric species.

\section{Egg laying, incubation, hatching}

All three species of Discus lay eggs most often on and in rotting timber; all cover the newly laid eggs with mucus. Adults of these three species are also associated with this kind of substratum. Some Discus parents carry some of their eggs inside the umbilicus for a varied period of time. The role of mucus and the significance of the substratum for egg-laying have been discussed elsewhere (KUŹNIK-KOWALSKA 1999); the egg-carrying habit will be dealt with in a separate paper (KUŹNIK-KOWALSKA \& POKRYSZKO in press).

In the laboratory D. ruderatus and D. rotundatus lay eggs throughout the year, $D$. ruderatus with maxima in June/July, D. rotundatus with a maximum in June. In contrast, the reproduction of $D$. perspectivus, apart from sporadic production of single eggs in winter, is limited to the period June-August. Likewise, in the field the youngest, newly hatched $D$. ruderatus appear in June but are still found, though less numerous, in October; D. rotundatus reproduces from April till August whereas $D$. perspectivus reproduces only from June till August, thus having the shortest reproductive period. The possible factors regulating the onset and termination of the reproductive period have been discussed by MALTZ (2003).

The number of eggs per batch and their size are similar in the three species of Discus: the mean egg size relative to parent size ranges from ca. 11\% (large

individuals of $D$. perspectivus) to ca. $18 \%$ (smaller individuals of $D$. ruderatus). The number of eggs per batch is small, and the mean number of eggs produced per lifetime ranges from 11 (D. ruderatus) to 32 (D. rotundatus). Another endodontid known in this respect, Punctum pygmaeum (Drap.) (BAUR 1989) produces single eggs of mean size $0.41 \times 0.50 \mathrm{~mm}$ and thus very large relative to the parent; the mean number of eggs per lifetime is 6 (range $1-16$ ). The relative egg size, their number per batch and per lifetime, seem to depend on the adult size and longevity (which in turn to a considerable extent depends on the size; HELLER 1990) rather then on the phylogenetic position of the species. Various species of the genus Vertigo (Vertiginidae), Vallonia pulchella (O. F. Müll) (Valloniidae) and Carychium tridentatum (Risso) (Ellobiidae), of a life span and size comparable to those of $P$. pygmaeum (data from WHITNEY 1938, BULMAN 1990, POKRYSZKO 1990, MYZYK 2005), lay eggs of a diameter equal to $30 \%$ largest dimension of the parent shell, most often singly, and their number per lifetime is low. Figures 9-11 present dependence between the adult size on the one hand and the relative egg size, number of eggs per batch and per lifetime, on the other. Slugs, semislugs and ovoviviparous snails have been omitted from the graphs, since they show different dependences between these parameters (cf. HELLER 1990 and references cited therein). Mean values for the graphs come from the following sources: WHITNEY (1938), VAIL (1978), WÄREBORN $(1979,1982)$, TOMPA (1984), BAUR (1989), BULMAN (1990), HELlER \& ITTIEL (1990), POKRYSZKO (1990), KORALEWSKA-BATURA (1999), MALTZ (2003), MYZYK (2005). In the graphs all three species of Discus occupy a position which could be expected, based on the size of the adults. 


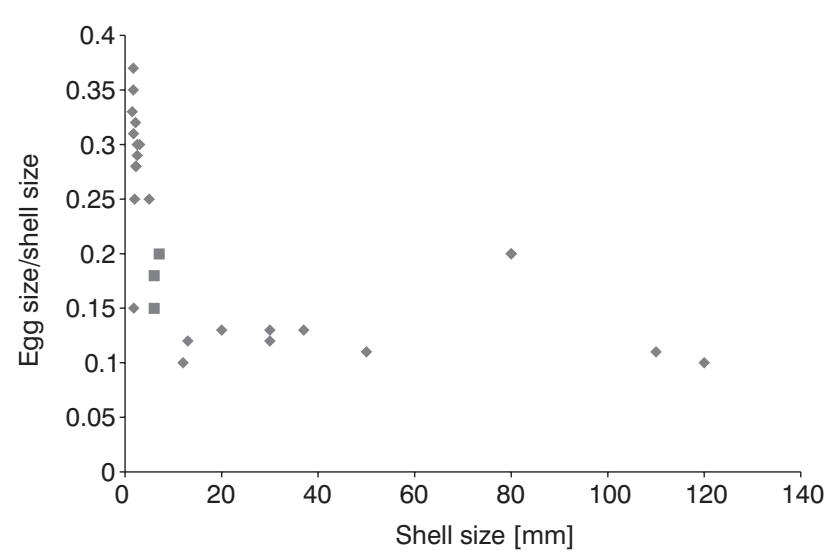

Fig. 9. Relative egg size plotted against parent size. Three species of Discus indicated with $\square$. For data sources see p. 40

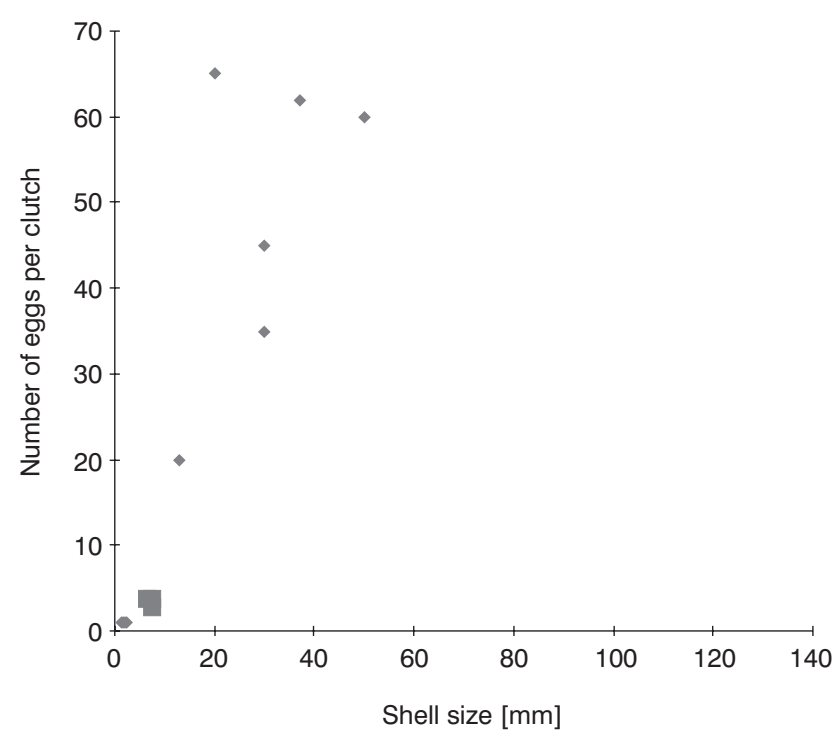

Fig. 10. Number of eggs per batch plotted against parent size. Three species of Discus indicated with $\square$. For data sources see p. 40

Such life cycle parameters as relative egg size, number of eggs per batch and per lifetime, as depending mainly on the adult size, seem to be of little use for phylogenetic considerations, at least concerning species of very different sizes, but may be useful when considering closely related species, of similar size and lifespan.

Like many other snail species (for review see TOMPA 1984, HeLler 1990), members of Discus cannot be unequivocally classified as either $\mathrm{r}$ - or K-strategists (SKELTON 1994). The graphs in Figures 9-11 suggest that in terrestrial snails the dependence between the body size and the life cycle parameters is the opposite to what the above strategies postulate: the smaller and more short-lived the snail, the lower its fertility.

The egg size may be corelated with the adult size also within species. In $D$. rotundatus the egg size is closely correlated with the adult size. A similar corre-

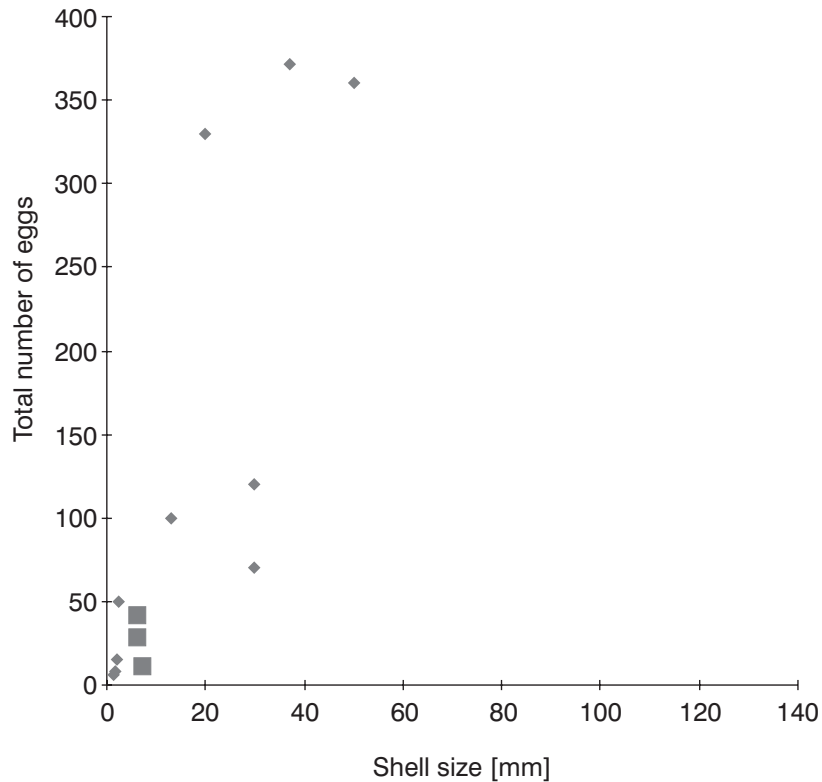

Fig. 11. Number of eggs per lifetime plotted against parent size. Three species of Discus indicated with $\square$. For data sources see p. 40

lation has been observed by BAUR $(1984,1990 \mathrm{~b})$ and BAUR \& RABOUD (1988) in Arianta arbustorum (L.), though the species does not grow when sexually mature and thus the egg size cannot change with the individual's age. The absence of such correlation in $D$. perspectivus and D. ruderatus is rather suprising.

The duration of incubation period in $D$. rotundatus and $D$. ruderatus varies very widely, and its mean values are similar. In $D$. perspectivus the variability range is smaller, and the mean incubation period - statistically significantly longer. In all three species the range of variation is too wide to be attributed solely to temperature differences, especially considering the stable laboratory conditions. The shells of newly hatched snails vary in the number of whorls, and here again the range is the smallest in $D$. perspectivus. Some differences may be explained by the variation of the non-ribbed, translucent, embryonic shell. However, most hatching snails have also the first few ribs of definitive whorls. Very wide ranges of the duration of incubation period are usually attributed to variable periods of egg retention in the parent's body (TOMPA 1984). Egg retention had been observed in two endodontids: a Helicodiscus (GUGLER 1972) and $P$. pygmaeum (BAUR 1989). Discus egg envelopes are opaque, which makes it impossible to assess the development stage of the embryo when the eggs are laid, but it is not likely that members of the genus retain eggs for any significant period of time, since no eggs are found in the reproductive system upon dissection. Furthermore, the incubation period in the egg-retaining $P$. pygmaeum ranges from 1 to 34 days (BAUR 1989), the range being ca. twice wider than in Discus. The distribution of the duration of incubation period would indicate periods of 20-25, 27-29 and 20-30 
days as normal for D. rotundatus, D. ruderatus and $D$. perspectivus, respectively, when the eggs are laid immediately after they have been formed.

The formation of the first fragment of the first definitive whorl (the first ribs) within the egg envelopes, before hatching, noted in all three members of Discus, has not ben observed in any other snail species. It might indicate that most juvenile Discus start feeding when still inside the egg envelopes and do it for a different period of time which may contribute to the variation in the duration of incubation period.

\section{Copulation}

No courtship and copulation could be observed in either D. ruderatus or D. perspectivus. The possible significance of the copulating position in D. rotundatus has been discussed by KUŹNIK-KOWALSKA (1999).

\section{Uniparental reproduction}

This mode of reproduction is regular in D. rotundatus, sporadic in D. ruderatus and has not been observed in $D$. perspectivus. In the last species it may be either completely absent, or its absence may result from the fact that the only reproducing individuals were those brought from the field as adults. The remaining two species, though they both reproduce readily in the laboratory and lay eggs throughout the year, differ clearly in the frequency of uniparental reproduction.

Individuals of $D$. rotundatus, kept singly, start reproducing later (at a higher number of whorls) than those kept in pairs and groups. Their eggs are smaller and fewer, in terms of the number per batch and per lifetime, than those of non-isolated individuals, and the differences are statistically significant. The number of eggs per lifetime in such individuals is 2-3 times smaller compared to non-isolated snails, and the hatching success is over twice smaller. The reproductive success of uniparental $D$. rotundatus is thus 3-4 lower, compared to non-isolated individuals. Normally developing juveniles hatched from four out of ten eggs laid by the only isolated $D$. ruderatus that laid eggs. The size of these eggs did not depart from those produced by non-isolated individuals. The low number of uniparental eggs in this case (some were eaten by the parent) does not allow for proper statistical comparison, but it seems that both the number of eggs and the hatching success are close to the respective parameters in snails kept in pairs and groups (11.5 and $53.85 \%$ ). The mechanism of uniparental reproduction - self-fertilisation or parthenogenesis - is unknown (for discussion see KUŹNIK-KOWALSKA 1999).

\section{Cannibalis m}

Juveniles of all three species readily eat conspecific eggs but, in their absence, D. ruderatus and $D$. rotundatus would also damage eggs of related species. The problems related to cannibalism (egg species rec- ognition, benefits of cannibalism, evolutionary context) have been discussed by BAUR (1988, 1990a) and KUŹNIK-KOWALSKA (1999). The three species differ in their preferences: D. perspectivus consumes only conspecific eggs, D. rotundatus eats eggs of the other two species very rarely, whereas $D$. ruderatus eats eggs of $D$. rotundatus (the only non-conspecific eggs offered to it in the tests) and conspecific eggs equally often. The results indicate differences in preference to conspecific eggs and/or ability to distinguish between conspecific and non-conspecific eggs. Both the preference and the ability to distinguish between the two kinds of eggs may result from early feeding experience (BAUR 1987a, 1988). Eggs of related species are probably accepted becuse of their chemical similarity to conspecific eggs.

Newly hatched $A$. arbustorum, fed with conspecific eggs, had a statistically significantly higher growth rate and matured earlier than individuals fed with plant food (BAUR 1986, 1990a). Cannibalistic D. rotundatus and $D$. ruderatus did not differ in their growth rate from normally fed snails, and matured at the same time. If cannibalistic Discus benefit from their cannibalism in any way, it is not terms of growth rate and maturation.

Since in all three species hatching is nearly synchronous within batches, exact tests for preferences to own/alien batches are impossible. Sporadic observations suggest, however, that, like A. arbustorum (BAUR 1987b), none of the three species is able to distinguish between own and alien batches.

Contrary to e.g. A. arbustorum which shows cannibalistic behaviour only during the first 16 days of its life (BAUR 1987a, b), all three species eat eggs, and $D$. rotundatus consumes also smaller and younger individuals, even when adult. In so far as the latter behaviour may be attributed to overdensity, the egg consumption by adults seems to be a normal behaviour.

\section{Growth and maturation}

The three species of Discus differ in their growth rate, but the growth pattern in all of them follows some general rules. They grow throughout life and form no lip. The growth from hatching to maturity is much faster compared to mature individuals. The shape of growth curves for $P$. pygmaum is similar (BAUR 1989). The slow growth in mature, reproducing $D$. rotundatus and $D$. ruderatus may be associated with energy and matter (including calcium) expenditure for relatively very large and heavily calcified eggs. This is supported by the larger size reached by isolated individuals which start reproducing later, compared to non-isolated snails. On the other hand, though $D$. perspectivus hatched in the laboratory never reproduced, their growth curves were the same as in the remaining two species. The explanation of the slowed-down growth in morphologically mature individuals cannot be based solely on reproduction-associ- 
ated energy and matter expenditure. For more discussion on growth rates in terrestrial snails see KU NIK-KOWALSKA (1999) amd MALTZ (2003).

The age at which maturity is reached (in terms of morphological characters of the reproductive system, the first egg laid and the presence of mature gametes in the gonad) is species-specific. The time from hatching to maturity is similar in D. ruderatus and $D$. rotundatus (229 and 252 days, respectively) and over twice longer in $D$. perspectivus (606 days). Size at maturity in terms of the number of whorls is very similar in $D$. rotundatus and D. perspectivus, and much smaller in D. ruderatus in which also the maximum attained number of whorls is much lower. The smallest number of whorls in individuals with morphologically mature reproductive system and mature gametes in their gonads is slightly over five (5.1-5.2) in D. rotundatus and $D$. perspectivus, and slightly over four (4.1-4.2) in $D$. ruderatus, while first eggs are laid by individuals of 5.5-6.55, 5.7-6.1 and 4.0-4.9 whorls, respectively.

\section{Life span}

The life span in all three Discus varies very widely. The mean life spans of laboratory individuals of $D$. rotundatus, D. perspectivus and D. ruderatus are ca. 955, 603 and 580 days, respectively. The highest recorded numbers of whorls for these three species are slightly over 6.8, 6.9 and 5.5-5.7 in the laboratory and 6.2, 6.2 and 4.5 in the field. This indicates that the life span in the laboratory is longer which probably results from a prolonged senile period (KOSIŃSKA 1980).

Subgeneric classification of Discus and the life cycle characters

The subgenera Discus s. str. and Gonyodiscus were based on characters of shell and reproductive system (UMIŃSKI 1962, RIEDEL \& WIKTOR 1974). The subgeneric characters are summarised in Table 6.

In the pertinent literature (WESTERLUND 1889, PILSBRY 1894, 1948, GEYER 1927, LINDHOLM 1927, THIELE 1931, FORCART 1957, UMIŃSKI 1962) there is no justification for the selection of characters, or assessment of their taxonomic suitability; in all probability the classification is not phylogenetic. Life cycle characters have not been used as a basis for snail classification to date, mainly because of the paucity of information. For the same reason it is difficult to estimate their suitability for phylogenetic inferences. Nonetheless, it is interesting to know to which extent the life cycle parameters are similar within and between the subgenera.

$D$. rotundatus and $D$. perspectivus are included in Gonyodiscus, D. ruderatus - in Discus s. str. Out of the 26 analysed characters (Table 7), six (incubation time, feeding inside egg envelopes, synchronous hatching, egg-carrying, duration of hatching, egg cannibalism) are similar in all three species. Not all of them seem to be of the same taxonomic value, but two are note- worthy. Building of the first fragment of the first definitive whorl before hatching has not been observed in any other snail group. Egg-carrying, found also in some other endodontids, will be discussed elsewhere (KUŹNIK-KOWALSKA \& POKRYSZKO in press).

Seven characters (egg size, egg shape, number of eggs per batch, number of whorls at hatching, number of whorls at first egg laying, number of whorls when the reproductive system becomes morphologically mature, number of whorls when the gonad contains mature gametes) are shared by $D$. rotundatus and D. perspectivus, both members of Gonyodiscus. The number of whorls at first egg laying and maturation of the reproductive system and gametes are inter-correlated, and also most probably correlated with the maximum number of whorls in adults. The size of eggs and their number per batch may result from the egg size-adult size-fertility dependence rather than from especially close relationship. The egg shape, different in each subgenus, seems to be of taxonomic value.

Three characters (number of batches, hatching success, life span) are common to D. perspectivus - a Gonyodiscus, and D. ruderatus - a Discus s. str. The number of batches per lifetime may, like the number of eggs per batch, result from the dependance egg size-adult size-life span (HELLER 1990) rather than from close relationship. The hatching success and life span are difficult to estimate from this viewpoint.

Three characters (time of whorl formation, time of whorl formation in growth phase I, potential reproduction throughout the year) are shared by $D$. rotundatus (Gonyodiscus) and D. ruderatus (Discus s. str.). Two of them, and especially the very similar shape of growth curves (similar overall growth rate and growth rate in phase I), somewhat different from that in $D$. perspectivus, and the potentially aseasonal reproduction, may actually support their close relationship.

The remaining characters (number of eggs per lifetime, time of whorl formation in growth phase II,

Table 6. Shell, reproductive system characters and distribution of Discus s. str. and Gonyodiscus

\begin{tabular}{lll}
\hline \multicolumn{1}{c}{$\begin{array}{c}\text { Character } \\
\text { subgenus }\end{array}$} & Discus s. str. & \multicolumn{1}{c}{ Gonyodiscus } \\
\hline $\begin{array}{l}\text { Penis } \\
\begin{array}{l}\text { Penial retrac- } \\
\text { tor insertion }\end{array}\end{array}$ & terminal & lateral \\
$\begin{array}{l}\text { Vas deferens } \\
\text { outlet }\end{array}$ & lateral & terminal \\
Prostate & $\begin{array}{l}\text { elongate, } \\
\text { poorly folded }\end{array}$ & $\begin{array}{l}\text { triangular or semi- } \\
\text { circular, strongly folded }\end{array}$ \\
Shell & $\begin{array}{l}\text { with no pat- } \\
\text { tern }\end{array}$ & with colour pattern \\
Distribution & Holarctic & Palaearctic \\
\hline
\end{tabular}


Table 7. Life cycle characters of D. rotundatus, D. perspectivus and D. ruderatus. For D. perspectivus the age at the first egg-laying is approximate; the number of eggs and batches per lifetime are based on life span, age at maturity and number of eggs per seson

\begin{tabular}{|c|c|c|c|}
\hline Character & D. rotundatus & D. perspectivus & D. ruderatus \\
\hline Egg diameter $[\mathrm{mm}]$ & $0.9-1.3 ; 1.10$ & $0.7-1.2 ; 0.95$ & $1.1-1.5 ; 1.29$ \\
\hline Egg shape & flattened oval & flattened oval & nearly sphaerical \\
\hline No. eggs per batch & $1-11 ; 4.3$ & $1-9 ; 3.9$ & $1-6 ; 3.0$ \\
\hline No. batches per lifetime & $1-36 ; 11.4$ & $3-9 ; 6.3$ & $2-6 ; 4.9$ \\
\hline No. eggs per lifetime & $1-178 ; 32.8$ & $8-33 ; 21.1$ & $6-15 ; 11.6$ \\
\hline Incubation [days] & $14-36 ; 23.4$ & $24-35 ; 29.4$ & $17-34 ; 25.0$ \\
\hline Hatching success $[\%]$ & 77.4 & 51.0 & 54.0 \\
\hline No. whorls at hatching & $1.5-2.4 ; 1.95$ & $1.8-2.3 ; 2.03$ & $1.5-2.5 ; 1.85$ \\
\hline Feeding inside egg envelopes & present & present & present \\
\hline Hatching & nearly synchronous & nearly synchronous & nearly synchronous \\
\hline Formation of 1 whorl [days] & $116.5-238.6 ; 215.0$ & $49.43-187.9 ; 127.3$ & $115.8-276.9 ; 178.6$ \\
\hline Formation of 1 whorl phase I [days] & $33.2-55.5 ; 42.8$ & $73-143 ; 101.0$ & $41.2-60.4 ; 51.4$ \\
\hline $\begin{array}{l}\text { Formation of } 1 \text { whorl } \\
\text { phase II [days] }\end{array}$ & $\begin{array}{l}787.1-2,096.6 \\
1038.3\end{array}$ & $60-725 ; 426.2$ & $213.3-745.6 ; 486.9$ \\
\hline Age at first egg laying [days] & $132-564 ; 272$ & $292-527 ; 426.2$ & $90-176 ; 119.4$ \\
\hline No. whorls at first egg laying [days] & $5.5-6.6$ & $5.7-6.1$ & $4.0-4.9$ \\
\hline $\begin{array}{l}\text { No. whorls at morphologically mature } \\
\text { genitalia }\end{array}$ & $5.1-5.2$ & $5.1-5.2$ & $4.1-4.2$ \\
\hline $\begin{array}{l}\text { No. whorls at appearance of mature } \\
\text { gametes }\end{array}$ & $5.1-5.2$ & $5.1-5.2$ & $4.1-4.2$ \\
\hline Uniparental reproduction & common & probably absent & very rare \\
\hline Life span [days] & $653-1,145 ; 954.8$ & $173-849 ; 603.3$ & $280-789 ; 580.0$ \\
\hline Senile period [days] & $50-551 ; 323.1$ & $312-557 ; 434.5$ & $87-521 ; 238.5$ \\
\hline Reproductive life [days \& \% life span] & $\begin{array}{l}102-546 ; 344.4 \\
37 \%\end{array}$ & $\begin{array}{l}16-83 ; 42.4 \\
7 \%\end{array}$ & $\begin{array}{l}5-509 ; 204 \\
35 \%\end{array}$ \\
\hline Egg-carrying & present & present & present \\
\hline Reproductive season lab \& field & $\begin{array}{l}\text { all year } \\
\text { May-October }\end{array}$ & $\begin{array}{l}\text { June-August } \\
\text { May-August }\end{array}$ & $\begin{array}{l}\text { all year } \\
\text { May-October }\end{array}$ \\
\hline Duration of hatching [hrs] & $1.5-2$ & $1.5-2$ & $1.5-3$ \\
\hline Cannibalism & present & present & present \\
\hline Consuming eggs of related species & rare & absent & frequent \\
\hline
\end{tabular}

age at first egg laying, uniparental reproduction, duration of senile period, reproductive life, consumption of non-conspecific eggs) are different in each of the studied species. In all, the analysed characters do not unequivocally support an especially close relationship between any two of the three species.

Life cycle characters, distribution and frequency of occurrence

The life cycle characters listed in Table 7 provide at least a partial answer to the question why $D$. perspectivus is the least and $D$. rotundatus the most common of the three species. D. rotundatus is the most fertile (in terms of the number of eggs per batch, number of batches and eggs per lifetime), has the shortest incubation period, the highest hatching success, the quickest growth to maturity and the longest relative reproductive life. Its reproduction seems to depend solely on habitat conditions, uniparental reproduction is common and efficient, and the life span is the longest. The ability to reproduce uniparentally, even with a rather low success, is one of the many attributes of good colonisers. In their studies on 14 species of terrestrial snails, MCCRACKEN \& SELANDER (1980) found that forms capable of uniparental reproduction occupied a wider range of habitats and more successfully colonised new areas. Though $D$. rotundatus is not the widest distributed Palaearctic Discus, it is the commonest and occupies the widest array of habitats. It is also the only member of the genus found in 
synanthropic habitats of Europe. D. perspectivus has the longest incubation period, the lowest hatching success, the slowest growth to maturity, the shortest reproductive life, strictly determined reproductive season, the shortest life span and probably no possi-

\section{REFERENCES}

BAUR B. 1984. Early maturity and breeding in Arianta arbustorum (L.) (Helicidae). J. Moll. Stud. 50: 241-242.

BAUR B. 1986. The influence of cannibalistic egg eating on the growth of young Arianta arbustorum (L.) (Helicidae). Snail Farming Research 1: 9-17.

BAUR B. 1987a. Effects of early feeding experience and age on the cannibalistic propensity of the land snail Arianta arbustorum. Can J. Zool. 65: 3068-3070.

BAUR B. 1987b. Can cannibalistic hatchlings of the land snail Arianta arbustorum distinguish between sib and non-sib eggs. Behaviour 103: 259-265.

BAUR B. 1988. Egg-species recognition in cannibalistic hatchlings of the land snails Arianta arbustorum and Helix pomatia. Experientia 44: 276-277.

BAUR B. 1989. Growth and reproduction of the minute land snail Punctum pygmaeum (Draparnaud). J. Moll. Stud. 55: 383-387.

BAUR B. 1990a. Possible benefits of egg canibalism in the land snail Arianta arbustorum (L.). Functional Ecology 4: 679-684.

BAUR B. 1990b. Seasonal changes in clutch size, egg size and mode of oviposition in Arianta arbustorum L. (Gastropoda) from alpine populations. Zool. Anz. 225: 253-254.

BAUR B. \& RABOUD C. 1988. Life history of the land snail Arianta arbustorum along an altitudinal gradient. J. Anim. Ecol. 57: 71-87.

BULMAN K. 1990. Life history of Carychium tridentatum (Risso, 1826) (Gastropoda: Pulmonata: Ellobiidae) in the laboratory. J. Conch. 33: 321-333.

EHRMANN P. 1933. Mollusken (Weichtiere). In: Die Tierwelt Mitteleuropas, II, 1. Leipzig.

FORCART L. 1957. Zur Taxionome und Nomenklatur von Gonyodiscus, Discus und Patula (Endodontidae). Arch. Moll. 86:1-3.

FRÖMMING E. 1954. Biologie der mitteleuropäischen Landgastropoden. Berlin.

GEYER D. 1927. Unsere Land- und Süsswasser-Mollusken. Stuttgart.

GUGLER C. 1972. Delayed oviposition in Helicodiscus. Bull. Am. Malacol. Union 10: 10.

HeLler J. 1990. Longevity in molluscs. Malacologia 31: 259-295.

Heller J., ITTIEL H. 1990. Natural history and population dynamics of the land snail Helix texta in Israel (Pulmonata: Helicidae). J. Moll. Stud. 56: 189-204.

KoralewSKA-BATURA E. 1999. Helix lutescens Rossmässler, 1837 (Gastropoda: Pulmonata: Helicidae) - its structure, biology and ecology. Folia Malacol. 7: 197-240. bility to reproduce uniparentally. With respect to the mentioned characters, $D$. ruderatus is intermediate between its two congeners.

KosińsKA M. 1980. The life cycle of Deroceras sturanyi (Simroth, 1894) (Pulmonata, Limacidae). Zool. Pol. 28: 113-155.

KUŹNIK-KOWALSKA E. 1999. Life cycle and population dynamics of Discus rotundatus (O. F. Müller, 1774) (Gastropoda: Pulmonata: Endodontidae). Folia Malacol. 7: 5-17.

KUŹNIK-KOWALSKA E. 2005. Life cycle and population dynamics of Discus perspectivus (Megerle von Mühlfeld, 1818) (Gastropoda: Pulmonata: Endodontidae). Folia Malacol. 13: $157-168$.

KUŹNIK-Kowalska E., POKRYSZKO B. M. in press. Incipient parental care in Discus - a plesiomorphic state of a truly endodontid character? J. Conch.

LINDHOLM W. 1927. Zur Nomenklatur einiger paläarktischer Landschnecken-Gattungen. Arch. Moll. 59: 6.

MALTZ T. K. 2003. Life cycle and population dynamics of $\mathrm{He}$ licodonta obvoluta (O. F. Müller, 1774) (Gastropoda: Pulmonata: Helicidae). Folia Malacol. 11: 63-88.

MCCraCKen G., SElander R. 1980. Self-fertilization and monogenetic strains in natural populations of terrestrial slugs. Proc. Nat. Acad. Sci. USA 77: 684-688.

MYZYK S. 2005. Egg structure of some vertiginid species (Gastropoda: Pulmonata: Vertiginidae). Folia Malacol. 14: 169-174.

PILsbry H. A. 1894. Helicidae, 7. In: Manual of Conchology, 9 (Tryon G. W., ed.). Philadelphia.

PILSBRY H. A. 1948. Land Mollusca of North America (North of Mexico), II, 2. Monogr. Acad. nat. Sci., Philadelphia 3.

POKRYSZKO B. M. 1990. Life history and population dynamics of Vertigo pusilla O. F. Müller, 1774 (Gastropoda: Pulmonata: Vertiginidae), with some notes on shell and genital variability. Ann. Zool. 43: 407-432.

RIEDEL A., WIKTOR A. 1974. Arionacea - ślimaki krążałkowate i ślinikowate (Gastropoda: Stylommatophora). Fauna Polski 2. PWN, Warszawa.

SKELTON P. 1994. Evolution. A biological and palaeontological approach. Addison-Wesley, Workingham, Reading.

STANISZ A. 1998. Przystępny kurs statystyki w oparciu o program Statistica PL, na przykładach z medycyny. StatSoft, Kraków.

THIELE J. 1931. Handbuch der systematischen Weichtierkunde 2. Jena.

TOMPA A. 1984. Land snails (Stylommatophora). In: Reproduction (TOMPA A. S., VERDONK N. H., VAN DEN BIGGLAAR J. A. M., eds), pp. 47-140, Academic Press, New York.

UMIŃSKI T. 1962. Revision of the Palearctic forms of the genus Discus Fitzinger, 1833 (Gastropoda, Endodontidae). Ann. Zool. 20: 299-333. 
VAIL V. A. 1978. Laboratory observations on the eggs and young of Triodopsis albolabris major (Pulmonata: Polygyridae). Malacol. Rev. 11: 39-46.

WÄREBORN I. 1979. Reproduction of two species of land snails in relation to calcium salts in the foerna layer. Malacologia 18: 177-180.

WÄREBORN I. 1982. Environments and molluscs in a noncalcareous forest area in southern Sweden. Depart. of. Animal Ecol. Univ. of Lund, Sweden. Dissertation 198, Lund.
WeSterlund C. A. 1889. Fauna der in der paläarktischen Region lebenden Binnenconchylien, 2. Berlin.

WHITNEY M. E. 1938. Some observations on the reproductive cycle of a common land snail, Vallonia pulchella. Influence of environmental factors. Proc. Indians. Acad. Sci. 47 (1937): 299-307.

WIKTOR A. 2004. Ślimaki lądowe Polski. Mantis, Olsztyn.

Received: December 15th, 2005 Accepted: February 20th, 2006 